\title{
Environmental factors of ensuring the competitiveness of construction enterprises
}

\author{
Viktoriya Mokhonko ${ }^{1}$, Natalia Blinova ${ }^{1}$, Lesia Sheludko $^{2}$, Sergiy Kobzan ${ }^{3}$, Anna \\ Tsyhenko $^{3}$, and Olena Uhodnikova, ${ }^{3, *}$ \\ ${ }^{1}$ Volodymyr Dahl East Ukrainian National University, Tsentralnyi prospect, 59-a, Severodonetsk, \\ 93400, Ukraine \\ ${ }^{2}$ Kharkiv National Agrarian University Named After V.V. Dokuchaiev, study KhNAU town, \\ Dokuchaevske, Kharkiv region, Ukraine, 62483 \\ ${ }^{3}$ O.M. Beketov Kharkiv National University of Urban Economy, Marshala Bazhanova Str. 17, 61002, \\ Kharkiv, Ukraine
}

\begin{abstract}
The article is devoted to certain aspects of ensuring the competitiveness of construction enterprises. In the context of the development of society, the requirements of people for the final products of construction production are significantly transformed. The processes of negative human impact on the environment are of high relevance in the world. Thus, the protection of ecology is gaining special relevance as a global priority for human development. construction, as a high-tech and resource-intensive sector of the economy, has special needs in the development of individual factors of competitiveness, taking into account the rationalization of the use of resources during construction processes, as well as at the stage of the direct operation of finished construction products. High material consumption determines additional requirements for the environmental friendliness of building materials and their rational use. These aspects are trends in the development of construction production. It is determined that the factors of competitiveness in the construction market based on the analysis of the development of construction in the leading countries of the world, it is possible to determine manufacturability, investment attractiveness, innovation. These factors have a direct relationship with the factors of ecological development, were investigated and built into the resulting diagram of the relationship between these factors, presented in the article. The regulatory and legal basis for ensuring the competitiveness of construction production, taking into account the factors of environmental safety, has been analyzed.
\end{abstract}

\section{Articulation of Issue}

In a highly competitive environment, to ensure the competitiveness of business entities, an important aspect is to take into account a set of factors that ensure the attractiveness of a product or service for consumers. Availability and flexibility of pricing policy, high quality

\footnotetext{
* Corresponding author: ugodnikova16@gmail.com
} 
of goods or services, after-sales service, advertising and marketing have already become familiar to consumers. Consequently, to ensure competitiveness, business entities are looking for new forms of meeting consumer needs that were not previously relevant. In conditions of a high degree of pollution of the atmosphere, soil and water, emissions of harmful substances, climate change and other consequences of man-made human impact on the environment, issues of ecology and environmental protection are becoming increasingly relevant. The technogenic impact of human activities on nature causes a number of negative environmental changes, which, in turn, negatively affect human life and health. So, the issues of ecological safety and environmental protection become an additional need for a person when making a choice of a particular product or service. Especially the issue of environmental safety is relevant in the field of construction, because a person spends most of his life in buildings (residential, office, industrial), or uses structures to meet the needs of his own life (utilities, transport movement, etc.). So, the operational processes of construction in the construction industry have a large anthropogenic impact on the environment, and the environmental indicators of the products themselves affect human life and health. So, given the relevance of the issue of environmental protection, ensuring the safety of life and health as the basic needs of people in the XXI century, it is advisable to determine the importance of environmental factors and their impact on ensuring the competitiveness of construction enterprises. Since 2010, a system of Eurocodes has been introduced in Ukraine - the introduction of standards used by the countries of the European Union into the State Building Norms in order to ensure the quality and reliability of construction products. According to these standards, the implementation of a construction project from the development of a project to its commissioning must comply with the normative document DSTU-N B EN [1], according to which the safety parameters of objects for humans and the environment, their technogenic impact and characteristics of rational operation, taking into account European standards are determined and consumption standards.

One of the trends in the modern construction industry is construction ecology - an area of activity related to the determination of the environmental characteristics of building materials and the technogenic impact of construction processes during the implementation of a construction project in order to ensure its environmental friendliness and further safety for human life and health. Thus, the article examines certain aspects of construction ecology as a factor in ensuring the competitiveness of the construction industry, taking into account European norms and standards for ecological construction.

\section{Analysis of the Latest Researches and Publications}

The issue of environmental safety and environmental protection is of high relevance, especially in the construction industry was indicated above. The relevance of the research issue has led to the attention to this issue of a number of domestic and foreign authors. In particular. O.S. Vengrina in her dissertation research determined the role of environmental aspects of construction in shaping the interests of stakeholders in investing in a construction project [1]. In the work of Ynes Zakura, the role of environmental factors is noted not only in direct construction processes, but also the influence of ecology on population settlement, respectively, the formation of centers of attraction that increase the competitiveness of construction products [2]. The mechanisms of environmental and economic incentives for enhancing the transition to biosphere construction are considered in the study by V.G. Shpakovoi [3]. Separate studies are devoted to the environmental issues of the development and implementation of environmentally friendly materials, the use of recycling systems, recycling of waste, in particular the work of Saliy I.M., Lyalyuk A.G., Ratushnyak A.G., Lyalyuk A.A., Shishkina E.A., Gaiko Y.I., Kostiantyn Viatkin [4-6]. Zhou, L. and Lowe, 
D. J. and Lucian O. investigated the economic aspects of the influence of environmental factors on the course of construction processes [7-8]. However, the constant development of technologies in construction and the growth of environmental problems determine the feasibility of forming new approaches to ensuring the competitiveness of construction by taking into account environmental factors.

\section{Purposes and Objectives}

The purpose of the article is to determine the influence of environmental factors on ensuring the competitiveness of construction products in the construction services market, taking into account the latest trends and trends in the world construction market.

For the purposes of the article, the research objectives are formulated, which can be defined as follows:

- analyze the latest trends and tendencies in the development of the construction industry in the world, in particular, the directions of ecological construction,

- to determine the relevance of the issue of environmental safety and impact on the environment as a factor in ensuring competitiveness in business,

- to determine the regulatory documents governing the issues of environmental safety and environmental protection in the implementation of construction projects,

- to propose the introduction of environmental indicators to the algorithm for the integral assessment of the competitiveness of construction enterprises.

\section{Statement of Basic Materials}

The development of the construction industry is a multiplier for the development of the country's economy, which is associated with the significant impact of construction production on the dynamics of macroeconomic indicators, as well as the development of related sectors of the national economy, including by providing these industries with fixed assets. The formation of fixed assets is one of the basic indicators of financial and economic analysis, determines financial stability, the ability of an enterprise to meet its short-term and long-term obligations, carry out operating activities and provide indicators of its own economic development. So, the construction industry has a great impact on the economy of both the state as a whole and the development of individual sectors of the national economy or business entities. construction plays a large social role, which is to provide the population with residential real estate in order to improve the comfort of their living, provide the population with social facilities, transport and communal infrastructure. So, the development of the construction industry has a large macro and microeconomic impact. Taking into account the influence of the construction industry on economic processes, it is advisable to note an increase in the volume of completed construction work in the world (excluding the quarantine period). It is advisable to present statistics of completed construction work in different countries of the world in 2019 - - fig. 1 [9].

Statistics show that the number of commissioned real estate in Ukraine, in comparison with other European countries and developed countries of the world is low. Thus, the highest indicator of commissioned real estate is presented in the United States, which is 1035 billion euros. This country has a large area, population and developed economy, which determines its leadership in this rating. Indicators of commissioning of housing in the United States in 2019 indicate the development of the country's economy and the improvement of living conditions for Americans, is a multiplier for the development of other sectors of the national economy [1]. 


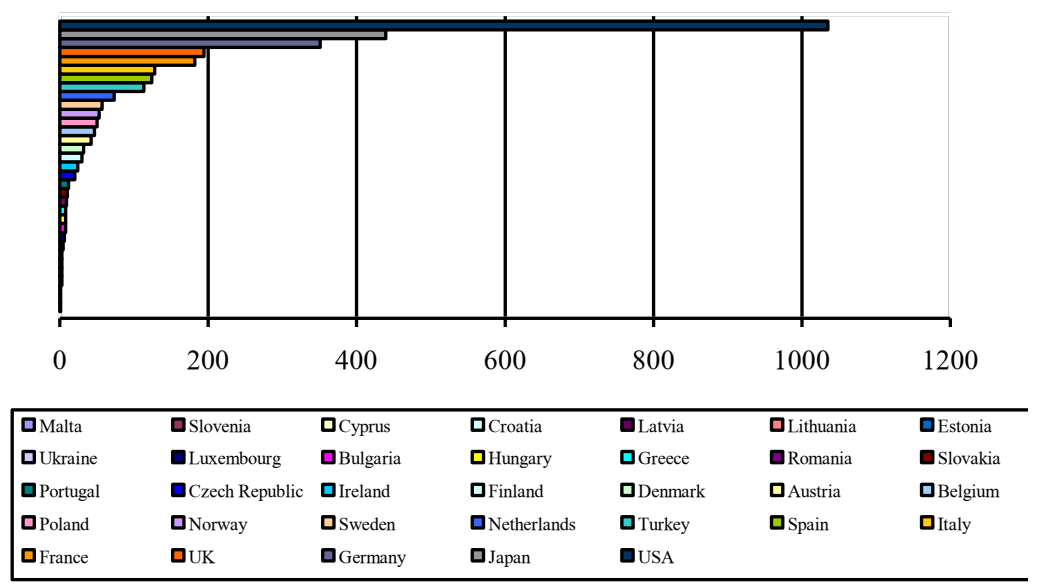

Fig. 1. Volumes of real estate construction in the leading countries of the world, billion euros, 2019

High rates of real estate commissioning were rearranged in Japan (439 billion euros), Germany (351 billion euros), Great Britain (194 billion euros). These countries have a stable developed economic system and are actively introducing innovative technologies, including in the construction industry. Among the developed countries of the European Union, they are actively developing the construction market, have a developed economy, are high-tech, and also actively develop the direction of tourism, is an additional factor in the development of the construction sector in connection with the development of the hotel industry, there are countries such as France (182 billion euros), Italy (128 billion euros), Spain (124 billion euros), Turkey (118 billion euros). Ukraine has quite low rates of commissioning of real estate, at the level of countries such as Romania, Bulgaria, Estonia, Latvia, Lithuania, Croatia. However, these countries are much smaller in area and population, therefore, the indicators of the number of commissioned real estate per person in Ukraine are significantly lower than in the EU and developed countries of the world. At the same time, in Ukraine, one of the lowest indicators of housing provision for the population is on average $18 \mathrm{sq}$. $\mathrm{m}$ per person. This indicator is significantly lower than in the EU countries [9].

At the same time, an important factor in ensuring competitiveness in the construction market is not only the amount of commissioned real estate, but also the quality of construction products. Among the quality indicators of construction products, the following factors can be identified [7-8]:

- performance characteristics,

- reliability, strength of structures,

- compliance with building codes during construction work,

- high-quality design documentation,

- energy efficiency,

- environmental characteristics of real estate.

Development trends of the construction industry in the leading countries of the world, which have high rates of production of construction products, indicate an increase in the role of environmental friendliness and energy efficiency in ensuring the competitiveness of construction products [3]. Eco-homes, zero-energy homes, smart homes are the leading technologies in the construction market today. Let's consider these technologies in more detail [4]. Eco-construction is one of the leading trends in the construction industry in the leading countries of the world. The introduction of eco-technologies in eco-buildings concerns both the use of environmental building materials that are safer for human health 
and the environment, rationalization of resource use, because the construction industry has a high resource intensity, the introduction of operational construction processes in accordance with the norms and standards of environmental safety [5]. Rationalization of resource use with a high consumption of resources for their use in operational processes may involve the use of secondary raw materials, production waste, used, for example, in order to improve the performance of traditional building materials, the use of recycled materials. The issue of rationalizing the use of resources, according to the concept of Sustainable Development of the United Nations, is one of the most urgent [6]. This is due to the constant trends towards an increase in the population, its needs, and, accordingly, the volume of resource consumption, are exhaustive, which may threaten the ability of future generations to live at the same technological level as previous generations. So, the issue of rationalizing the use of resources is a priority to ensure the strategic development of the construction market. According to the requirements of the modern construction market, technologies have been developed for the construction of houses with zero energy consumption, that is, using energy saving and energy efficiency technologies. These technologies are associated not only with the use of alternative sources of energy supply to buildings, but also with technologies that allow energy to be used rationally, while ensuring the comfort of people in these buildings.

It is advisable to determine that for the domestic construction market, the use of environmental technologies is an additional factor of competitiveness, but only on the condition that this factor does not affect the pricing policy for the sale of finished real estate. Ensuring the introduction of innovative technologies in the domestic economic system is determined by a number of regulatory documents, in particular:

- The Law of Ukraine "On Investment Activity" [10],

- The Law of Ukraine "On Scientific and Scientific and Technical Activities" [11],

- The Law of Ukraine "On Priority Areas of Innovative Activity in Ukraine" [12].

These regulatory documents determine the issues of introducing innovative technologies in various sectors of the economy.

The Law of Ukraine "On Investment Activity states that investments can be defined as" types of property and intellectual values invested in objects of entrepreneurial and other types of activity, as a result of which a profit (income) is created and / or a social and environmental effect is achieved [10 article 1 ]. So, the issue of investment attractiveness is closely related to the formation of social and environmental effects. This formulation is important for the construction industry. The specificity of the construction market lies in the fact that all construction customers are, in fact, investors, because most construction projects are implemented in whole or in part at the expense of the funds of persons expecting to receive construction products in the future period of time. So, investment attractiveness is a basic indicator of ensuring the competitiveness of construction companies. According to the regulatory and legal approaches to the formation of the concept of investment, the urgency of issues of the environmental effect from investment projects is determined, therefore, the dependence of the environmental direction of construction and the competitiveness of construction enterprises is confirmed.

Analysis of trends in the development of the construction market in the leading countries of the world has determined the high role of technological development of construction processes. Thus, one of the factors of the competitiveness of construction production can be determined by the introduction of innovative technologies. In Ukraine, technological innovations are regulated by the Law of Ukraine "On Scientific and Scientific-Technical Activities". Article 46 of this regulatory document defines the basis for the regulation of scientific and scientific and technical activities, the basic of which is "compliance with environmental safety requirements" [11, Article 46]. So, as one of the 
factors ensuring the competitiveness of construction enterprises - technologization - directly depends on the factors of environmental development.

In accordance with the Law of Ukraine "On Priority Areas of Innovation in Ukraine," priority is given for the development of innovations, namely: "aimed at ensuring the economic security of the state, creating high-tech competitive environmentally friendly products, providing high-quality services and increasing the export potential of the state with the effective use of domestic and world scientific and technological achievements "[12, article 2]. So, the factor of environmental safety is the basic factor of innovation, enshrined at the legislative level.

So, analyzing the latest trends and trends in the development of the construction industry, the following can be determined:

- technologization - the development of new technologies associated with increasing the comfort of construction products, as well as ensuring an optimal price-quality ratio,

- innovativeness - the introduction of new technologies or innovative operational processes, operational characteristics, real estate, previously not presented on the market, is an additional factor of competitiveness,

- attracting investments by increasing investment attractiveness, one of the factors of which is precisely the factor of environmental safety.

Having determined the basic factors of competitive construction production, it is advisable to analyze the relationship of these factors with the factors of environmental development, presented in fig. 2

\begin{tabular}{|l|l|}
\hline Technologisation & $\begin{array}{l}\text { compliance with environmental safety } \\
\text { requirements }\end{array}$ \\
\hline Innovations & $\begin{array}{l}\text { the basic priority is to create high-tech } \\
\text { competitive environmentally friendly products }\end{array}$ \\
\hline Investments & the social and ecological effect is reached \\
\hline
\end{tabular}

Fig. 2. The scheme of interrelation of factors of maintenance of competitiveness and ecological factors

So, the analysis of trends in the development of the construction industry, and the analysis of the regulatory framework for construction activities determined the basic priorities for ensuring the competitiveness of construction products in modern conditions of economic development, in particular, the processes of introducing technologies, innovative approaches to construction production and ensuring the investment attractiveness of construction enterprises. The study identifies the relationship between priority factors for ensuring competitiveness with factors of environmental development, environmental protection and safety for the life and health of consumers of construction services.

\section{Conclusions}

As a result of the analysis, the influence of environmental factors on ensuring the competitiveness of construction enterprises was determined. By analyzing the volume of construction products produced, the countries that are leaders in the construction industry at the global level were identified. The trends in the development of the construction market in the leading countries of the world have determined that the trends of ecological 
construction and construction, taking into account the requirements of rational use of resources, in particular energy efficiency, are of high relevance. These technologies are innovative for the domestic construction market, therefore, the requirements of the legislation to ensure the innovative development of the construction market are determined. Among the factors of ensuring the competitiveness of construction enterprises, taking into account modern requirements for the comfortable use of construction products, manufacturability, innovation and investment attractiveness were identified. The article analyzes the regulatory and legal approaches to the definition of these factors, and the influence of these factors on ensuring environmental development in the framework of the implementation of construction processes and the market launch of finished construction products.

\section{References}

1. O. S. Venhrina, Modeli ta metody upravlinnia zmistom proektu redevelopmentu $\mathrm{z}$ urakhuvanniam interesiv steikkholderiv: dys. kand. tekhn. nauk: 05.13.22 Kharkivskyi natsion. univursytet misk. hospod., Kharkiv, 173 (2018)

2. Y. Zakur, Arkhitekturno-planuvalni kontseptsii ekolohichnykh poselen ta perspektyvy yikhnoho vtilennia v Ukraini : kvalifikatsiina robota mahistra spetsialnosti 192 "Budivnytstvo ta tsyvilna inzheneriia", nauk. kerivnyk V. O. Savin. Zaporizhzhia : ZNU, 116 (2020)

3. journals.uran.ua (Last accessed 21.12.2020)

4. I. M. Salii, Suchasni ukrainski budivelni materialy, vyroby ta konstruktsii: naukovopraktychnyi dovidnyk; za red. K.K. Pushkarovoi; Asotsiatsiia «Vseukrainskyi soiuz vyrobnykiv bud. materialiv ta vyrobiv» (Kyiv, VSVBMV, 2012)

5. O. H. Lialiuk, O. H. Ratushniak, A. O. Lialiuk, Ekolohichnyi menedzhment vidkhodiv budivelnoho vyrobnytstva, Suchasni tekhnolohii, materialy i konstruktsii $\mathrm{v}$ budivnytstvi, 1, 94-100 (2017)

6. E. A. Shyshkin, YuI Haiko, K. I. Viatkin, Retsyklinh budivelnykh vidkhodiv. Mistobuduvannia ta terytorialne planuvannia (2018) irbis-nbuv.gov.ua (Last accessed 29.12.2020)

7. L. Zhou, D. J. Lowe, Economic Challenge of Sustainable Construction [Electronic resource] : In Proceedings of the RICS Construction and Building Research Conference, School of Engineering and the Built Environment, University of Wolverhampton, UK, 1-2 September, Edited by D Proverbs 113-126 (2003) URL: https://www.academia.

edu/15077696/Economic_Challenge_of_Sustainable_Construction. - Nazva z ekranu. (Last accessed 11.12.2020)

8. O. Lucian, The importance of economic analysis in investment projects, Ocneanu Lucian, Radu Cristian Buc§ä, Economy transdisciplinarity cognition, 17(2), 84-92 (2014)

9. Vseukrainska spilka vyrobnykiv budivelnykh materialiv. Stroytelnyi portal №1, Novosty.. Analytyka rynka: Stroytelnyi rynok. Obsiahy budivnytstva ta vyrobnytstva budivelnykh materialiv v Ukraini: realna sytuatsiia. http://avbmv.som.ua (Last accessed 22.12.2020)

10. Ofitsiinyi sait Verkhovnoi Rady Ukrainy. Zakon Ukrainy «Pro investytsiinu diialnist», 47, 646 (Vidomosti Verkhovnoi Rady Ukrainy VVR, 1991) https://zakon.rada.gov.ua/laws/show/1560-12\#Text (Last accessed 22.12.2020) 
11. Ofitsiinyi sait Verkhovnoi Rady Ukrainy. Zakon Ukrainy Pro naukovu i naukovotekhnichnu diialnist, 25, 3 (Vidomosti Verkhovnoi Rady (VVR), 2016) https://zakon.rada.gov.ua/laws/show/848-19\#Text (Last accessed 22.12.2020)

12. Ofitsiinyi sait Verkhovnoi Rady Ukrainy. Zakon Ukrainy Pro priorytetni napriamy innovatsiinoi diialnosti v Ukraini, 166, 19-20 (Vidomosti Verkhovnoi Rady Ukrainy (VVR), 2012) URL: https://zakon.rada.gov.ua/laws/show/3715-17\#Text (Last accessed 23.12.2020) 